\title{
Problemas ambientais decorrentes de estações de tratamento de esgoto (ETEs) em Santa Catarina
}

\author{
Francisco Gelinski Neto* \\ Carmen Rosario O. G. Gelinski**
}

\section{Resumo}

Os problemas ambientais que afetam o homem são decorrentes em grande parte da poluição provocada pela própria espécie. São, por exemplo, reduções de cardumes nas zonas costeiras devido à poluição dos mares; tempestades, secas extremas em razão das mudanças climáticas; doenças respiratórias e neurológicas devido a gases emanados de esgotos mal tratados e ou sem tratamento. Este trabalho se preocupa com a poluição do ar decorrente de gases tóxicos emitidos nas estações de tratamento de esgoto (ETEs). Para isso são estudadas as ETEs do Bairro Potecas em São José/SC, administrada pela Casan e a de Jarivatuba, gerida pela Companhia Águas de Joinville/SC. O objetivo central é analisar a situação das duas ETEs quanto ao tratamento das emissões de gases e verificar a percepção da população quanto aos problemas e soluções para o mau cheiro de gases emitidos. Entrevistaram-se técnicos e gerentes das empresas e moradores do bairro Potecas e verificaram-se dados secundários constatando-se que as soluções para emissão de gases poluidores foram diferentes. A Águas de Joinville mudou para o tratamento aeróbico (não gera gases) e a Casan permaneceu com o processo anaeróbico (gera gases). A Casan não tem conseguido sanar os problemas e continua gerando poluição trazendo insegurança para a população do entorno da ETE.

Palavras-chave: poluição, tratamento de esgoto, ETEs

\section{Environmental problems arising out of sewag treatment stations (ETEs) in Santa Catarina}

\begin{abstract}
The environmental problems that affect man are due largely to the pollution caused by the species itself. For example, there are reductions of schools in coastal areas due to pollution of the seas; storms, extreme droughts due to climate change; respiratory and neurological diseases due to gases emanating from poorly treated and untreated sewage. This work is concerned with air pollution from toxic gases emitted at sewage treatment plants (ETEs in portuguese). To this end, the ETEs of the Potecas Neighborhood in São José / SC, administered by Casan and the Jarivatuba, managed by Companhia Águas de Joinville / SC are studied. The central objective is to analyze the situation of the two ETEs regarding the treatment of gas emissions and verify the perception of the population regarding the problems and solutions for the bad smell of gases emitted. Technicians and managers of the companies and residents of the Potecas neighborhood were interviewed and secondary data were verified, showing that the solutions for emission of polluting gases were different. Águas de Joinville changed to aerobic treatment (it does not generate gases) and Casan remained with the anaerobic process (it generates gases). Casan has not been able to cure the problems and continues to generate pollution bringing insecurity to the population around the ETE.
\end{abstract}

Key words: pollution, sewage treatment, ETEs

JEL: Q5, Q53

\footnotetext{
* Professor do Departamento de Economia e Relações Internacionais da Universidade Federal de Santa Catarina (UFSC). E-mail: f.gelinski@ufsc.br e fgelneto@gmail.com

** Professora do Departamento de Economia e Relações Internacionais da Universidade Federal de Santa Catarina (UFSC). E-mail: carmen.gelinski@ufsc.br
} 


\section{Introdução}

Embora o Brasil tenha assumido compromisso internacional com a redução de emissões de gases de efeito estufa existem dificuldades relacionadas, por exemplo, à eliminação de gases das atividades da pecuária (especialmente na biodigestão do esterco dos suínos) e no tratamento de esgotos urbanos. Os gases gerados por estas atividades se não tratados se tornam um problema ambiental.

Os problemas ambientais que tem afetado a humanidade trazendo elevado risco estão em diversas frentes - mares, atmosfera e solo, conforme destaca o PNUMA (Programa das Nações Unidas para o Meio Ambiente). As crises ecológicas globais, destacadas na última reunião da Assembleia Ambiental da ONU (Organização das Nações Unidas) realizada no Quênia em dezembro de 2017, estão sustentadas por abundantes notícias negativas (AGENDA...., 2017). Por exemplo, as emergências ligadas à saúde pública provocada pela poluição do ar na China, na Cidade do México e outros exemplos ${ }^{1}$. No mar a poluição por plásticos e isopor e mesmo resíduos orgânicos também são conhecidos ${ }^{2}$. A preocupação com o solo vão desde poluições por resíduos de metais pesados até lixões sem controle e erosões que degradam o mesmo. A água está cada vez mais preocupando a humanidade pelo risco de sua falta, e por que ela pode provocar erosões carreando resíduos ou como componente de situações de precipitações extremas e ou falta absoluta da mesma. A poluição da água afeta a segurança alimentar. Por exemplo, já está acontecendo redução de oferta de pescados em diversos países por esta poluição. “(...) há zonas pesqueiras mortas perto da costa em função da poluição das águas"3 (CHIARETTI 2012, p. A9). Os dados da ONU mostram que a poluição do ar é a que mais mata seres humanos, seriam sete milhões de pessoas ao ano (AGENDA...., 2017, p. A12). Este trabalho preocupa-se com a poluição do ar.

A poluição do ar acontece por presença de particulados e gases oriundos das diversas atividades humanas. São automóveis e caminhões, fábricas e mesmo singelas atividade como utilização de assopradores para limpeza de pátios e terrenos, que acabam jogando milhares de partículas na atmosfera. Os gases são oriundos de fermentações de resíduos e também de

\footnotetext{
${ }^{1}$ A china promoveu a expulsão de empresas do centro de Pequim como forma de reduzir a pressão populacional e a poluição decorrentes das atividades humanas na área central da cidade (QI, 2016).

2 Seriam incorporados 8 milhões de toneladas de plásticos anualmente nos oceanos segundo a ONU Chiaretti (2012).

${ }^{3}$ Estas preocupações foram destacadas Joseph Alcamo cientista-chefe do Pnuma entrevistado por Chiaretti (2012). Os peixes representariam 10\% das calorias consumidas diariamente pelos humanos e $25 \%$ dos recursos já estão super explorados.
} 
atividades industriais e agrícolas. A manipulação de esgotos e bombeamentos podem carrear bactérias e fungos para o ar transmitindo doenças.

Gelinski Neto et al. (2017) verificaram as dificuldades encontradas no processo de eliminação de gases de efeito estufa em tratamento com biodigestores no caso de estercos suínos ${ }^{4}$. Algumas delas referem-se à dificuldade de manutenção do sistema, controle das lonas/bolhas de coleta do gás e retirada de resíduos dos depósitos.

No caso do tratamento de esgotos urbanos dificuldades parecidas surgiram, conforme apontado pela mídia e entrevistados na Estação de Tratamento de Esgoto de Araraquara (SP) e a do Bairro Potecas em São José (SC). Dias (2017) descreveu as dificuldades operacionais e a perda de eficiência da ETE de Araraquara por assoreamento dos tanques de tratamento, que exigiram recursos vultuosos para solução dos problemas.

Este artigo analisa o caso do tratamento de esgotos urbanos em Santa Catarina, mais especificamente o caso da ETE (Estação de tratamento de esgoto) do Bairro Potecas em São José na Grande Florianópolis que está sob responsabilidade da CASAN (Companhia Catarinense de Águas e Saneamento) e, a ETE de Jarivatuba da Companhia Águas de Joinville.

Há necessidade real de que sejam intensificadas ações tecnológicas para solucionar as emissões de gases por dois motivos: primeiro, os compromissos assumidos pelo Brasil relativamente à redução de emissões de gases de efeito estufa; e, segundo, pelo fato de haver doenças relacionadas à exposição de humanos aos diversos gases oriundos de esgotos não corretamente tratados.

Os esgotos podem gerar gás sulfídrico e gás metano. O gás sulfídrico ${ }^{5}$ e o gás metano presentes nas fermentações anaeróbicas de $\operatorname{esgotos}^{6}$ podem provocar desde irritação respiratória até problemas neurológicos como irritabilidade, dores de cabeça e perda de memória. Além disso, bactérias, vírus e fungos podem viajar no ar a partir do esgoto bruto

\footnotetext{
${ }^{4} \mathrm{O}$ fenômeno conhecido como "efeito estufa" ocorre quando a radiação solar, que chega ao Planeta na forma de ondas curtas, passa pela atmosfera, aquece a superfície terrestre, refletindo de volta para a atmosfera parte dessa radiação na forma de calor, em comprimentos de onda infravermelha. Na presença de alguns elementos gasosos da atmosfera a reflexão é bloqueada e, dessa forma, intensificando a retenção de calor nas camadas mais baixas da atmosfera. Esse fenômeno é natural e importante para a manutenção da temperatura, considerada dentro dos limites aceitáveis à vida no Planeta (MAPA, 2011, p.9).

${ }^{5}$ É o mesmo que sulfeto de hidrogênio ou quando em solução aquosa denominado de ácido sulfrídrico. É obtido pela decomposição de resíduos em condições anaeróbicas. É um gás com odor a ovo podre e inflamável. Se houver exposição aguda ao gás o ser humano corre sérios riscos inclusive de morte. Exemplos: taquicardia, bronquites, depressão respiratória e até paralisia respiratória. Entre os efeitos neurológicos citam-se: vertigem, irritabilidade, dor de cabeça, tontura, tosse, convulsões e até estado de coma. Os sintomas são acompanhados de náuseas, vômitos e diarreia. Veja mais em http://tratabrasil.org.br/a-saude-afetada-pelos-odores-provenientes-doefluente-domestico-e-o-problema-dos-esgotos-a-ceu-aberto-2

${ }^{6}$ Fermentações anaeróbicas são aquelas que ocorrem em ambiente sem oxigênio, realizadas por bactérias. Já as fermentações aeróbicas são aqueles que ocorrem na presença de oxigênio.
} 
provocando diversas doenças que vão de tuberculose a disenteria, conforme apontam Mucciacito e Cordeiro (2014).

O fato relevante é o elevado percentual de emissões oriundas dos esgotos urbanos. "A coleta e o tratamento de esgotos nas áreas urbanas geram $31,4 \%$ das emissões do setor" (RESÍDUOS, s.d., p.1). Além de tudo, as emissões estão se elevando rapidamente, pois, entre 1990 a 2014 o crescimento foi de 150\% em termos de dióxido de carbono, segundo a mesma fonte.

As ETEs de Potecas (São José/Florianópolis) e de Jarivatuba (Joinville) têm sido obrigadas a fazer adequações devido aos problemas ambientais, que afetam diretamente as populações do seu entorno. A CASAN, que administra a ETE de Potecas, tem sofrido pressão popular que, inclusive, desencadeou abertura de processo pelo Ministério Público de Santa Catarina pedindo transferência da estação, em ação ajuizada em junho de 2016 e retirada em outubro de 2017 (THOMÉ, 2017). A empresa assumiu novos compromissos com o ajuste de conduta. Jarivatuba, sob responsabilidade da Cia. Águas de Joinville, também precisou desenvolver projeto alternativo além de fazer adequações no modelo da estação. A antiga estação era no mesmo modelo utilizado pela CASAN na ETE de Potecas, pois, foi a mesma empresa que construiu em Joinvile.

A preocupação central deste trabalho é analisar a situação das duas ETEs relativamente aos esquemas de tratamento das emissões de gases, e verificar a percepção da população quanto aos problemas e soluções para o mau cheiro e gases emitidos.

O trabalho foi desenvolvido com base em dados secundários e primários. Estes últimos obtidos por meio de entrevistas semiestruturadas que visam sustentar a pesquisa de caráter exploratório. Foram entrevistados técnicos nas duas empresas e o gerente de políticas operacionais da CASAN. Em Potecas, foram entrevistados moradores com grande proximidade das lagoas de decantação e funcionários do posto de saúde do bairro. Em termos de área geográfica, o estudo envolveu o Bairro de Jarivatuba em Joinville (ETE) e o Bairro de Potecas (ETE). É um estudo da área acadêmica da economia, economia ambiental e da energia. Especificamente se pretende verificar: i) os efeitos perversos da poluição do ar; ii) os efeitos negativos das ETEs percebidos pela população; iii) tipos de tratamentos para eliminação de gases nas ETEs; iv) se há aproveitamento energético de gases gerados nas ETEs; e, v) o potencial de ampliação de biogás de tratamento de esgoto no Brasil.

\section{A poluição, seus efeitos e possibilidades}


Nesta seção, são feitas considerações sobre poluição na legislação brasileira e, as consequências da poluição aos seres humanos. A Política Nacional do Meio Ambiente, no seu artigo $3^{\mathrm{a}}$ da Lei de $\mathrm{n}^{\mathrm{o}}$ 6.938/81 considera a poluição como a degradação da qualidade ambiental resultante de atividades que direta ou indiretamente: i) prejudiquem a saúde, a segurança e o bem-estar da população; ii) criem condições adversas às atividades sociais e econômicas; iii) afetem desfavoravelmente a biota; iv) afetem as condições estéticas ou sanitárias do meio ambiente; e, v) lancem matérias ou energia em desacordo com os padrões ambientais estabelecidos (BRASIL 1981). O manuseio durante o tratamento dos dejetos humanos nas estações de tratamento pode provocar poluição atmosférica por meio de gases e ou materiais particulados e mesmo micro-organismos patogênicos (MUCCIACITO, CORDEIRO, 2014). No caso das ETEs, a poluição é percebida por maus odores que afetam as populações do entorno das mesmas.

“Os maus odores têm sido os responsáveis pelos fortes protestos e reclamações de uma população ligada a estes incômodos. (...) Os principais pontos de emissão dos odores nas ETEs incluem as elevatórias, o pré-tratamento, o espessador e a desidratação do lodo" (CARVALHO, 2001, p.XII). Das tecnologias para reduzir os odores, a autora analisou a utilização da biofiltração com leito de turfa e concluiu que o processo tem boa eficiência na redução dos gases odorantes.

"Existem tecnologias capazes de melhorar consideravelmente a qualidade do ar. Mas os políticos, míopes, tendem a se concentrar nos custos das ações em vez de considerar os custos de manter os braços cruzados" (UPTON, 2016, p.A11) ${ }^{7}$.

Os custos da poluição e seu tratamento não são apenas os referentes às soluções tecnológicas para redução das emissões dos gases do efeito estufa, ou seja, os gastos diretos, mas também aqueles referentes aos problemas ocasionados pelos gases e/ou materiais particulados aos humanos. Neste caso, existem os custos com perda de eficiência/produtividade e vidas humanas ocasionados pela poluição do ar (UPTON, 2016).

Upton (2016) menciona Relatório da OCDE (Organização para Cooperação e Desenvolvimento Econômico) que estima em 6 a 9 milhões o número de mortes prematuras por ano devido à exposição à poluição do ar até $2060^{8}$. Seria equivalente à morte de uma pessoa a cada 4 a 5 segundos ${ }^{9}$. Apenas no ano de 2010 foram três milhões vitimados pela poluição do ar.

\footnotetext{
7 Vale destacar que este trabalho não possui o foco da Engenharia Sanitária de soluções tecnológicas para o problema dos gases e odores gerados por estações de tratamento de esgoto.

${ }^{8}$ Trata-se do Relatório “Avaliação de Riscos de Mortalidade Políticas Ambientais, de Saúde e Transportes".

${ }^{9}$ Seriam 200 milhões de pessoas morrendo prematuramente nos próximos 45 anos.
} 
O mesmo estudo da OCDE destaca a intensificação de doenças devido à poluição atmosférica. Será 3 vezes maior o número de casos de bronquite em crianças atingindo o valor de 36 milhões por ano até 2060 e, no caso de adultos serão 10 milhões de casos anuais até aquele ano comparativamente aos 3,5 milhões anuais que ocorrem na atualidade. Também, os casos de asma serão muito mais frequentes. Para cálculos monetários, considera-se que em 2060 serão 3,75 bilhões de dias de trabalho perdidos por ano devido às doenças decorrentes do ar poluído. O custo das mortes prematuras poderá alcançar entre US\$ 18 a US\$ 25 trilhões por ano em 2060. Somando-se as perdas na saúde humana, a reduções de produtividade na agricultura poderá ultrapassar 1\% do PIB ou US\$ 2,6 trilhões ao ano (UPTON, 2016).

É hora de os governos pararem de discutir sobre custos dos esforços para limitar a poluição do ar e começarem a preocupar-se com os custos muito maiores decorrentes de tolerar a poluição. As vidas desses cidadãos estão nas mãos desses governos (UPTON, 2016, p. A 11).

Há uma série de ações práticas que poderiam reduzir os particulados na atmosfera urbana, dentre elas: a lavação por caminhão pipa de ruas movimentadas, a restrição e/ou proibição no uso de máquinas denominadas vassouras de vento (que também poluem com elevado nível de ruído), a regulação no uso de máquinas de cortar cerâmica e físcalização de indústrias em geral ou, ainda, a circulação de caminhões com carrocerias sujas com resíduos que deveria ser fortemente coibida por espalhar materiais ao longo do seu trajeto.

\section{0 efeito estufa, o biogás e a geração de energia}

Nesta seção verificam-se os efeitos climáticos perversos decorrentes de gases de efeito estufa e o uso do biogás no Brasil. Pode-se analisar a questão do biogás e do metano nele contido sob duas óticas. A primeira, relativa aos malefícios ambientais (gases de efeito estufa e doenças em humanos por intoxicação); e, a segunda, referente ao desperdício energético quando o gás não é aproveitado.

$\mathrm{Na}$ primeira ótica, a preocupação principal é quanto às mudanças climáticas decorrentes do efeito estufa. Estas seriam a principal questão na agenda internacional sobre meio ambiente desde as negociações do Protocolo de Quioto em 1997 (PLATIAU, 2011). Na realidade, as conferências sobre meio ambiente iniciaram em 1972 na Suécia e as COPs (Conferências das Partes) sobre clima ${ }^{10}$ iniciaram em 1995. Elas têm por objetivo estabelecer as regras de funcionamento do regime internacional que abrangeria desde o cumprimento das emissões de carbono até restrições às importações de bens e taxações sobre produtos entre

\footnotetext{
${ }^{10}$ É órgão supremo da Convenção Quadro das Nações Unidas sobre Mudança do Clima (UNFCCC) que reúne os países anualmente desde 1995 em capitais e outras cidades importantes.
} 
outras. Portanto, a agenda internacional sobre as mudanças climáticas envolve debates e decisões de “(...) dimensão ambiental, energética, econômica e comercial” (PLATIAU, 2011, p.19). Na COP-15, realizada em Copenhague no ano de 2009, o Brasil comprometeu-se a reduzir as emissões de GEE até 2020 entre 36,1\% e 38,9\%, abaixo do que era em 2005.

As mudanças climáticas decorrentes do efeito estufa podem, por exemplo, acidificar os oceanos devido ao aumento do dióxido de carbono (CO2), trazendo sérias alterações sobre a cadeia alimentar dos oceanos devido à dissolução de micro-organismos marinhos entre outros impactos (TOLEDO, s.d). Além disso, a elevação de temperatura aumentará consideravelmente o nível dos oceanos.

Caso as emissões de gases do efeito estufa continuem crescendo às atuais taxas ao longo dos próximos anos, a temperatura do planeta poderá aumentar até 4,8 graus Celsius neste século - o que poderá resultar em uma elevação de até 82 centímetros no nível do mar e causar danos importantes na maior parte das regiões costeiras do globo (TOLEDO, s.d ., p.1).

Os cientistas do $5^{\circ}$ Relatório do IPCC (Painel Intergovernamental sobre Mudanças Climáticas) acreditam que as taxas de $\mathrm{CO} 2$, metano e óxido nitroso do último século sejam as mais altas dos últimos 22 mil anos (TOLEDO, s.d).

Na segunda ótica, a preocupação reside no desperdício energético devido à perda do metano. Não existe no Brasil o aproveitamento em larga escala dos gases gerados no tratamento de esgotos e de produções animais. Por exemplo, Gardemann (2017) declara que o Brasil desperdiça energia limpa e renovável, no caso do biogás e do biometano quando faz a queima de combustível fóssil para atender a demanda do Sistema Interligado Nacional (SIN) na geração de energia elétrica. Ele também considera que o Brasil, por ser um dos maiores produtores agropecuários do mundo e com uma população de 207 milhões, teria matéria prima de sobra para produzir a energia limpa e renovável, no caso o biogás e o biometano.

A Associação Brasileira de Biogás e Biometano (Abiogás) estima que o potencial brasileiro de biogás é de 52 bilhões de metros cúbicos por ano, sendo 39 bilhões oriundos do setor sucroenergético, 9 bilhões do setor de alimentos e 4 bilhões do setor de saneamento. Caso todo esse potencial fosse aproveitado, supriria $24 \%$ da demanda elétrica do país, ou reduziria em $44 \%$ o uso de diesel (GARDEMANN, 2017, p.1) ${ }^{11}$.

Os dados do Sistema Nacional de Informações sobre Saneamento (SNIS) mostram elevado potencial de geração de biogás de esgoto urbano, pois em média apenas $50 \%$ da população era atendida por esgotos coletados em 2015. Estas informações não indicam sobre aproveitamento energético do biogás. No caso das 100 maiores cidades brasileiras, o índice sobe para $70 \%$ de esgoto coletado. Considerando-se o tratamento de esgoto percentualmente à água consumida pela população em geral o índice fica em 41\%. Nas 100 maiores cidades, o

\footnotetext{
${ }^{11}$ Alessandro Gardemann é presidente da ABIOGÁS.
} 
índice atinge 51\%. Entre 2011 e 2015 o crescimento percentual destes indicadores foi de $2,16 \%$ ao ano e de $5,17 \%$ ao ano de aumento da coleta e de aumento do tratamento do esgoto coletado. Portanto, praticamente $50 \%$ do esgoto ainda não é coletado e percentual parecido de esgoto coletado não tratado (TRATA BRASIL, 2017).

Dados recentes apontam queda de 26,2\% nos investimentos em esgotamento sanitário no Brasil entre 2015 e 2016. O ano de 2016 teve menor volume investido da série iniciada em 2008. Foram apenas 4,24 bilhões de reais em 2016. A GO Associados, consultores da área, projetam que a universalização (100\% da população atendida) do esgotamento sanitário no Brasil (prevista no Plano Nacional de Saneamento Básico para 2023) somente será atingida em 2054. Isso devido aos problemas fiscais e menores receitas das operadoras estaduais de saneamento que tiveram impactados os seus investimentos nos últimos anos - 2015, $2016 \mathrm{e}$ 2017 (TAIAR, 2018).

Aos poucos, o Brasil está incorporando a biogás na matriz energética. Porém, a utilização de biogás para geração de energia ainda é incipiente. Note-se que dos 14,5 GW gerados por usinas de biomassa no Brasil apenas 130 megawatts (menos de 10\%) são oriundos de usinas de biogás (33 projetos). Destaque-se, ainda, que os 14,5 GW corresponderiam a apenas $8,9 \%$ da geração de energia do país ${ }^{12}$ (GARDEMANN, 2017). Portanto, haveria ainda elevado potencial para ampliação no uso do biogás.

Com os problemas associados à crise energética e ao aquecimento global, vários países têm investido montantes significativos em tecnologias e projetos para o aproveitamento do biogás. Como recurso renovável, o uso do biogás colabora com a não dependência de fonte de energia fóssil; aumenta a oferta e possibilita a geração descentralizada de energia próxima aos centros de carga; promove economia no processo de tratamento de esgoto, aumentando a viabilidade da implantação de serviços de saneamento básico (PNUD/MMA, 2010, p. 3).

Na região Sul do Brasil, segundo a gerência de meio ambiente da CASAN, um projeto no Paraná seria o primeiro para produção de energia a partir de gases obtidos de resíduos urbanos e esgoto ${ }^{13}$. Trata-se de projeto desenvolvido pela SANEPAR (Companhia de Saneamento do Paraná) em parceria com Cattalini Bio Energia “(...) que produz energia elétrica, térmica e biofertilizante a partir da biodigestão de resíduo resultantes do tratamento de esgoto e de compostos orgânicos coletados de grandes empresas como shoppings e restaurantes" (GARDEMANN, 2017, p.1). A usina deverá produzir 2,8 MW com a utilização da energia dos gases da biodigestão dos resíduos. A figura 1 mostra como deverá ficar a usina depois de pronta. Ela aproveitará resíduos de origem sanitária.

\footnotetext{
${ }^{12}$ Dados do Banco de Informações de Geração (BIG) da Agência Nacional de Energia Elétrica (Aneel) citado por Abiogás (2017).

${ }^{13}$ Entrevista no dia 14/03/2018.
} 


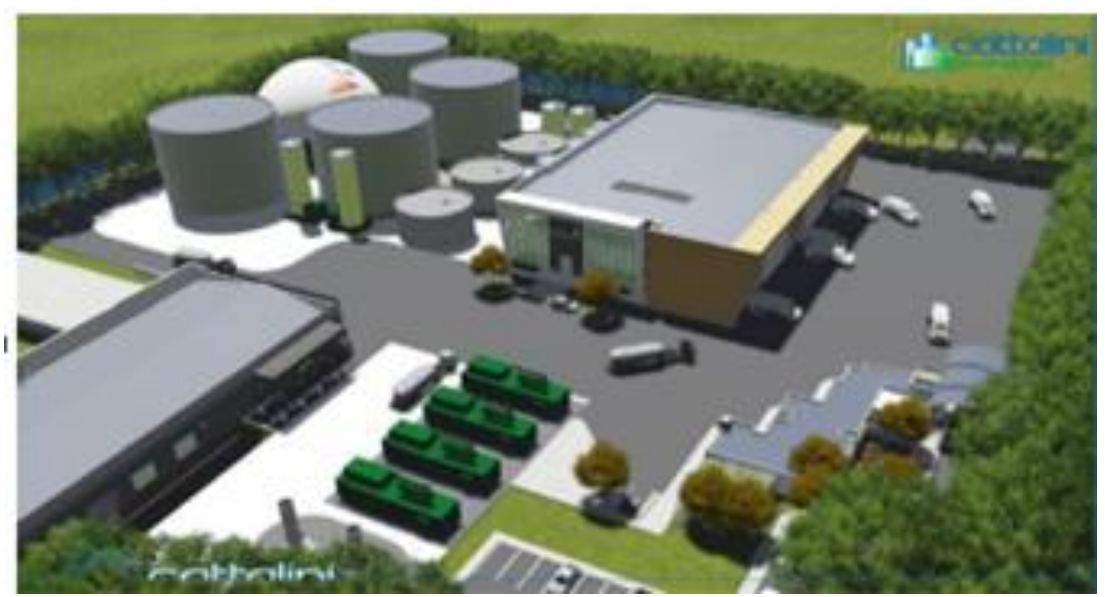

Figura 1 - Modelo de biodigestores da CS Bioenergia (Sanepar e Catallini) Fonte: Dreger (2017), slide 13.

Outro exemplo de utilização do biogás em maior escala foi estabelecido por meio da criação do Programa Paulista de Biogás em 2012, e que ainda está em fase de maturação. O estado de São Paulo pode determinar o percentual mínimo de biometano possível de ser injetado na rede de gás canalizado que é distribuído pelas concessionárias estaduais de gás. Ficam estas obrigadas a adquirirem o biometano produzido no Estado por um período de 8 anos. Estas resoluções ainda aguardavam, em novembro de 2017, a aprovação do Conselho Estadual de Política Energética para posterior validação da agência reguladora estadual (Arsesp) (GARDEMANN, 2017). A figura 2 mostra um modelo de biodigestor para material de origem sanitária em Riberão Preto.

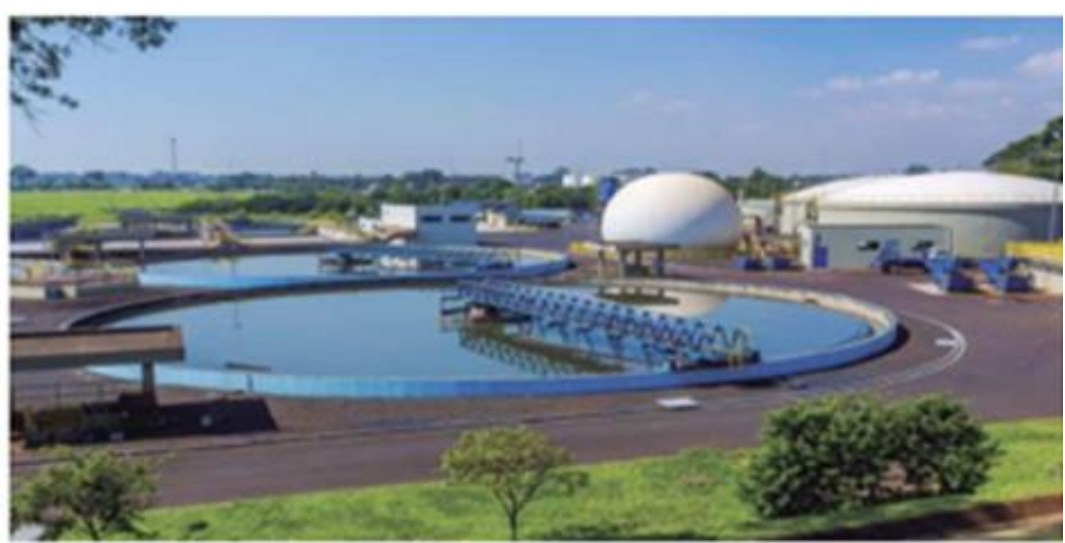

Figura 2 - Modelo de biodigestores da ETE Ribeirão Preto (Ambient) Fonte: Dreger (2017), slide 13.

Portanto, na visão de Gardemann (2017), o biogás deixa de ser atividade de pequena escala e/ou de nicho para se tornar uma fonte de geração de energia nobre e com alto potencial para suprir energia à matriz elétrica brasileira. Além disso, o aproveitamento do gás metano contribuiria para o país reduzir as emissões de $\mathrm{CO} 2$ e alcançar os compromissos firmados durante a Conferência das Nações Unidas sobre Mudança Climática (COP21), em 
Paris $^{14}$. Lembrando que o Brasil se comprometeu a promover redução das emissões de gás carbônico (DREGER, 2017).

O estado de Santa Catarina está procurando regulamentar a produção e uso do biogás por meio do estabelecimento de marco legal. A partir de projeto proposto pelo Deputado Estadual Natalino Lázare, discutido e aprovado na Câmara Legislativa, o governador sancionou em 12/07/2018 a Lei N 17542 que instituiu a Política Estadual do Biogás. Com essa lei, criaram-se possibilidades reais para exploração de biogás e biometano dentro de Santa Catarina. Nessa direção, a Secretaria da Agricultura do Estado já sugeriu a criação do Programa Catarinense do Biogás (SC-Biogás). Neste trabalho o interesse são os serviços de saneamento que foram contemplados no artigo 20 da proposta de lei. Poderá haver concessão de exploração de biogás no âmbito das instalações de tratamento de resíduos sólidos urbanos e esgotamento sanitário. Além disto, o Estado poderá fomentar o biogás e o biometano a partir de biomassa em seu território, por meio de programas específicos conforme estabelece o artigo 22 .

Acredita-se que a autogeração de energia, caso do biogás, poderá elevar-se em Santa Catarina, pois o Estado deu importante passo para estimular a autogeração uma vez que está retirando a incidência de ICMS para a energia autogerada por famílias e/ou empresas ${ }^{15}$. Estaria faltando apenas a aprovação do CONFAZ e, posteriormente, da Assembleia Legislativa estadual que deverá aprová-la facilmente. Fato importante porque a maior reclamação era justamente a cobrança de ICMS sobre a autogeração (BENETTI, 2018), que era um claro desestímulo econômico e com certeza restringia a sua ampliação.

O esgoto tem boa capacidade para gerar biogás ${ }^{16}$. Na comparação entre diversas fontes verificou-se que: a silagem de milho e o capim geram os maiores volumes de biogás por metro cúbico de massa fresca, porém possuem menor teor percentual de metano em relação à outros materiais (DREGER, 2017). A silagem de milho e o capim produzem, respectivamente, 202 e 172 metros cúbicos de biogás por tonelada de massa fresca, porém o percentual de gás metano é de apenas 52 e 54\%. O Quadro 1 mostra a comparação em termos do biogás produzido por tonelada de matéria fresca e o percentual de metano encontrado no biogás de cada material. Note-se que o resíduo orgânico de cozinha possui o melhor indicador

\footnotetext{
${ }^{14} \mathrm{O}$ metano é 20 vezes mais poluente que o gás carbônico $(\mathrm{CO} 2)$.

${ }^{15}$ Novidade divulgada na Câmara de Assuntos de Energia da Federação das Indústrias do Estado (FIESC) pelo presidente da Associação de Produtores de Energia de Santa Catarina (APESC) na reunião do dia 12/3/2018 (BENETTI, 2018).

${ }^{16}$ O biogás é um gás composto por metano e gás sulfídrico e outros, em composição percentual variável em função do material que é utilizado para sua produção.
} 
em termos de biogás gerado, e também, possui bom índice percentual de metano comparativamente aos demais materiais/resíduos.

Quadro 1 - Comparativo biogás produzido por tipo de material e \% de metano

\begin{tabular}{|l|c|c|}
\hline Tipo de biomassa/material & $\begin{array}{c}\text { Biogás produzido/Biomassa } \\
(\mathrm{MF}=\text { Massa Fresca) }\end{array}$ & Metano gerado (\%) \\
\hline Orgânico de cozinha & $100 \mathrm{~m}^{3 / t} \mathrm{MF}$ & 61 \\
\hline Esterco de aves & $80 \mathrm{~m}^{3} / \mathrm{t} \mathrm{MF}$ & 60 \\
\hline Dejetos líquidos de suíno & $18-28 \mathrm{~m}^{3} / \mathrm{t} \mathrm{MF}$ & 65 \\
\hline Esterco líquido de bovino & $25 \mathrm{~m}^{3} / \mathrm{t} \mathrm{MF}$ & 60 \\
\hline
\end{tabular}

Fonte: Dreger (2017), slide 13

Considerando-se que o metano é um gás muito prejudicial como gerador de efeito estufa, os materiais do Quadro 1 seriam mais poluentes comparativamente à silagem de milho e capim que geram ao redor de $50 \%$ de gás metano.

Além das questões tributárias e problemas relacionados a recursos para investimento, a adequada precificação do carbono são elementos com possibilidade de induzirem ou restringirem a ampliação da atividade de biogás no Brasil.

A Iniciativa Empresarial em Clima (IEC) concluiu que é necessária a implementação de um mecanismo de precificação de carbono no Brasil, como uma alternativa para reduzir as emissões de gases de efeito estufa (GEE) ${ }^{17}$. Na visão de Flavia Resende, presidente do Instituto Ethos, isto seria um estímulo aos empresários, governo e consumidores para emprego de tecnologias não poluentes e práticas mais sustentáveis. Esses estímulos são importantes dados os elevados valores necessários para aplicações tecnológicas redutoras de carbono. O volume de investimentos globalmente atingiria US\$ 5,7 trilhões ao ano até 2020 para reduzir o carbono na atmosfera e assegurar o cumprimento do acordo de Paris (temperatura global não ultrapassar elevação de $\left.2^{\circ} \mathrm{C}\right)(\mathrm{KISS}, 2016$, p. F4).

Embora existam expectativas positivas no caso da geração energética a partir o biogás, ela pode não atingir expectativas. Rodrigues, Aquino e Estevam (2011) verificaram que numa estação de tratamento de esgoto em São Paulo, que ainda não produzia metano, se fosse produzir energia a partir do metano esta seria insuficiente. Cobriria apenas $50 \%$ do requerimento total de energia da estação. Porém, nessa simulação tratava-se de unidade de tratamento de esgoto já instalada e que deveria ser adaptada.

\section{Os problemas das ETEs}

\footnotetext{
${ }^{17}$ A referida conclusão ocorreu por ocasião da Conferência Ethos $360^{\circ}$ (KISS, 2016). 
Além das visitas e das entrevistas com moradores e técnicos, as imagens subsidiaram a análise sobre a ETE de Potecas/CASAN. Por exemplo, a figura 3 mostra a proximidade da escola com a estação de tratamento que está logo após a vegetação que aparece ao fundo do lado direito. Acontece que essa vegetação é apenas um pequeno cordão de isolamento da lagoa de decantação.

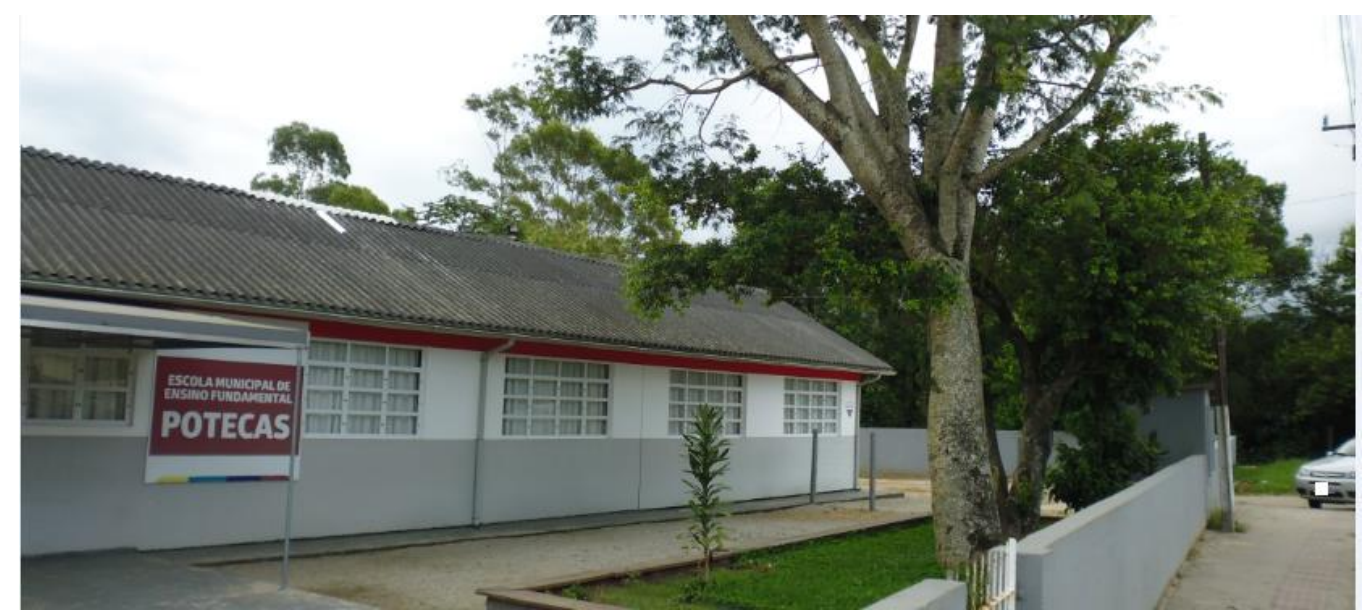

Figura 3 - Escola Municipal de Potecas ao lado do lago da ETE Fonte: Foto dos autores em 03/03/2018

A exígua distância entre a escola e a lagoa de decantação pode ser observada na figura 4. Na foto de satélite, a escola se encontra na seta branca em baixo lado direito (A).

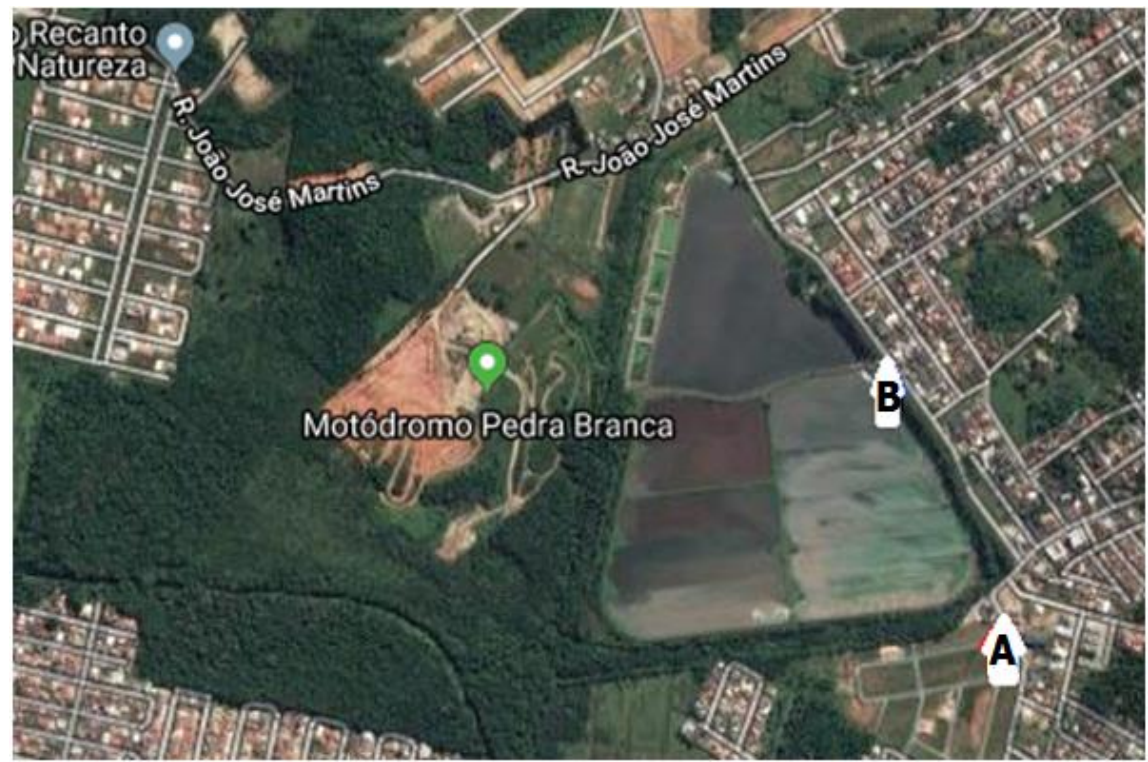

Figura 4 - Foto aérea ETE Potecas e aglomerações no entorno Fonte: Google, acesso 06/03/2018.

Legenda: (A) Escola; (B) Bombas elevatórias da ETE

A péssima localização da escola, devido à ínfima distância faz que os alunos sofram o impacto direto dos gases emanados de toda a estação. Conforme a direção do vento, a poluição vai direto para a escola. Isto já provocou reclamação de funcionários da escola por 
afetar a saúde dos estudantes e tornar o ambiente irrespirável, a ponto de necessitarem suspender aulas durante os períodos críticos, pois os estudantes têm náuseas e dor de cabeça. O que salta à vista é o irrisório cordão de isolamento por vegetação no entorno da ETE de Potecas ${ }^{18}$. Também, surge a pergunta. Por que o poder público municipal permitiu a instalação de loteamento e a instalação de serviços públicos (escola, posto de saúde) próximos à fonte poluidora? ${ }^{19} \mathrm{~A}$ assessoria de imprensa da CASAN afirmou, em 2017, que a companhia estaria investindo mais de 3 milhões de reais para fazer as readequações e manutenções necessárias para resolver o problema dos maus odores na ETE de Potecas. Este valor parece uma pequena fração do que a Cia. Águas de Joinville investiu apenas na ETE de Jarivatuba (ao redor de 90 milhões de reais) para resolver o mesmo problema. Saliente-se que lá eles construíram uma nova com outro sistema de tratamento. Não estariam mais produzindo e queimando o gás que provoca os maus odores.

A produção, coleta e queima de biogás no caso do tratamento de esgotos nas ETEs não é um processo tecnológico simples. Isto também foi verificado no caso de tratamento de resíduos da suinocultura, conforme levantaram Gelinski Neto et al. $(2017)^{20}$. No caso das Estações de Tratamento de Esgoto que utilizam o processo de fermentação anaeróbico têm ocorrido problemas (rachaduras das bolhas de coleta de gases, assoreamento dos depósitos). Estes problemas, por exemplo, aconteceram em Araraquara (SP) e na ETE do Bairro Potecas (CASAN) em São José na Grande Florianópolis (SC).

A Figura 5 mostra o local aonde o esgoto urbano chega ao seu destino para tratamento primário e separação de materiais, conduzido pela tubulação vermelha ao fundo (na borda do lago). Ali, o esgoto é tratado para posterior liberação nas lagoas de decantação. Nesse local, o gás gerado no processo anaeróbico deverá ser coletado e queimado. A citada tubulação vermelha inicia na estação elevatória que é o ponto de entrada do esgoto na ETE.

\footnotetext{
${ }^{18}$ A insalubridade é tamanha que há 10 anos a $10^{a}$ Promotoria de Justiça da Comarca de São José investiga a situação e, há um ano, ajuizou uma ação civil pública contra a Casan, pedindo a retirada da Lagoa de Estabilização (THOMÉ, 2017, p.1).

19 Talvez o Prefeito Municipal de São José tenha editado algum Projeto de Lei Complementar acabando com a exigência de no mínimo 500 metros de distância de ETEs e residências. Ver exemplo de Uberaba/MG, cujo prefeito fez exatamente isto por meio do PJC 19/2015. http://www.jmonline.com.br/novo/?noticias, 6,POLITICA, 113349

${ }^{20}$ Foram verificadas dificuldades operacionais de manutenção de equipamentos e retirada de lodo do fundo dos depósitos. Baixa eficiência técnica e econômica de determinados equipamentos. A presença de determinados componentes químicos que reduziam a vida útil dos equipamentos pela corrosão entre outros.
} 


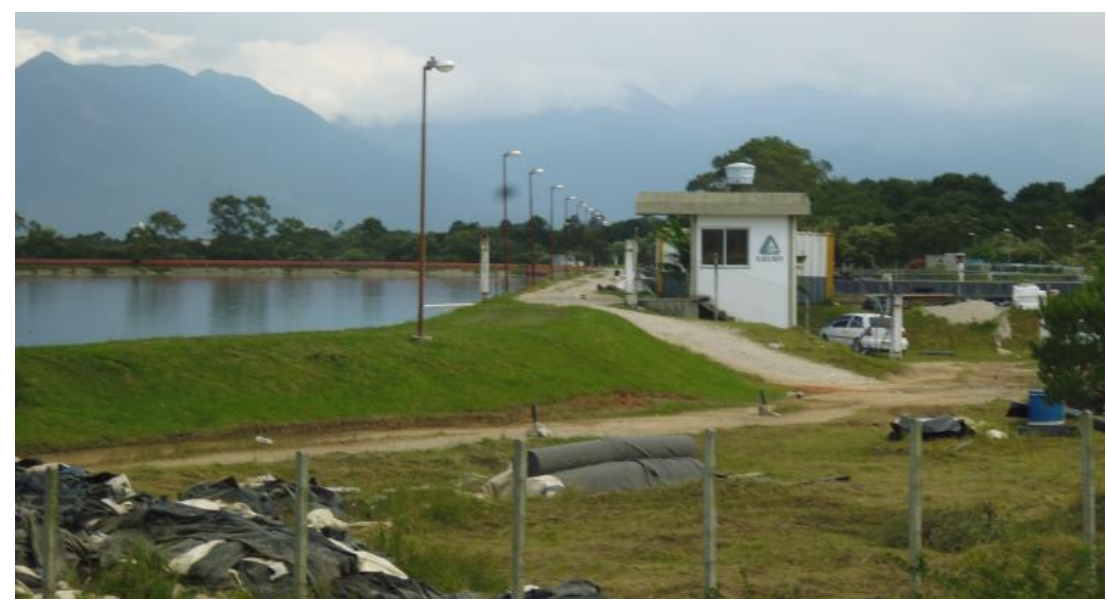

Figura 5 - Fundos da ETE de Potecas

Fonte: fotos dos autores em 03/03/2018

A Companhia Águas de Joinville resolveu o problema do lodo de sedimentação da ETE de Jarivatuba por meio da remoção por dragagem e filtragem em grandes bolsas de material têxtil permeável reduzindo, assim, o mau cheiro e melhorando o funcionamento da ETE que será desativada assim que a outra esteja pronta ${ }^{21}$. A companhia de Joinville está construindo moderna ETE no mesmo local com investimento de R\$ 93 milhões com capacidade triplicada em relação à atual ETE e com promessa de ser uma das mais modernas da América Latina (MARTENDAL, 2018). O novo sistema permitirá a desativação das lagoas de estabilização.

As estações mais antigas como, por exemplo, a do Bairro Potecas (Florianópolis) e a ETE de Jarivatuba (Joinville) possuem o processo anaeróbico, que gera mais gases poluidores do ambiente (metano e sulfídrico). Por isso, quando a população cresce em seu entorno passa a reclamar e exigir mudanças. No caso da ETE de Joinville (administrada pela companhia Águas de Joinville) a estação está sendo construída a partir do zero, em uma nova concepção que vai utilizar o processo de aeração prolongada que não gera gases. A estação antiga que vem da década dos 80 está sendo desativada. É um processo aeróbico que utiliza injeção de ar na massa. A promessa é que será uma das mais modernas da América Latina. No Caso da ETE de Potecas (CASAN) está ocorrendo remodelação no sistema de coleta de gás, conforme será descrito posteriormente ${ }^{22}$. Saliente-se que a visualização da fotografia aérea (Figura 4) permite inferir que já está ocorrendo assoreamento dos lagos de decantação e, talvez seja necessária a dragagem e filtragem em bags como fez a ETE de Jarivatuba.

\footnotetext{
${ }^{21}$ Este sistema de filtragem (bags) é o mesmo utilizado pela SANEPAR no Parque Bariguí.

${ }^{22}$ A referida estação é uma das mais antigas da CASAN, em operação desde a década de 1990. Com o passar dos anos o entorno passou a ser ocupado, e começaram a surgir reclamações dos novos moradores pelo cheiro exalado das lagoas que fazem o tratamento. Desde 2010 funciona com reator anaeróbio além das três lagoas de estabilização, com tratamento do tipo secundário. A vazão média é de 277 litros por segundo com capacidade total de até417 1/s (CASAN, 2016).
} 


\subsection{Entrevistas com funcionários da CASAN}

Em entrevista com funcionários locais da ETE de Potecas/CASAN verificou-se que a companhia teve que remodelar o sistema de coleta do gás, justamente pelas dificuldades parecidas com aquelas dos grandes reservatórios de gás dos biodigestores da suinocultura ${ }^{23}$. Com o tempo a lona rachava ou afundava nos resíduos dificultando o insuflamento e, portanto, a armazenagem, coleta e queima do gás. A manutenção era dificultosa, o que impedia maior eficiência na gestão do gás. Assim, conforme esclarecimento dos funcionários locais, a empresa optou por novo formato de coleta por lona inflável que está suspensa em mecanismo de boias flutuantes. Até o mês de abril de 2018, o sistema de queima deverá iniciar o funcionamento conforme informou a gerência de Políticas Operacionais da empresa.

Para a CASAN um aspecto positivo foi a resolução do grande problema de maus odores da ETE do Centro de Florianópolis, localizada próxima à Rodoviária, logo na entrada da cidade. Essa ETE mudou o sistema de tratamento para o gás, fazendo com que o mesmo seja filtrado em um Biofiltro e removeu o mau cheiro que impregnava a região. Foi feita uma vedação no depósito que recebe o esgoto e uma captação do gás com injeção do mesmo em material poroso que contém microrganismos que fazem a eliminação do gás, conforme informou um engenheiro sanitarista. Das ETEs do Município algumas possuem queimadores para eliminação do gás gerado.

A CASAN e a Águas de Joinville não geram energia quando fazem a queima dos gases gerados no tratamento dos dejetos humanos. Um dos entrevistados da CASAN afirmou que o esgoto urbano teria menor eficiência de geração de gás frente ao esterco suíno e, por isto, renderia menor poder energético. Esta informação não confere com os valores do Quadro 1. Ele mostra o elevado volume de biogás gerado e também o elevado percentual de geração de metano do esgoto doméstico comparativamente ao esterco suíno. De toda forma vale a pena traçar um paralelo com o estímulo que há em países da Europa para que os produtores agrícolas obtenham gases de diversas fontes, para a geração de energia inclusive com subsídios para tal (BOLETIM INFORMATIVO FAEP/SENAR, 2017) ${ }^{24}$. Aparentemente, no caso das Concessionárias de Saneamento estamos perdendo um recurso quando simplesmente

\footnotetext{
${ }^{23}$ GELINSKI NETO et alii (2017) analisam este problema.

${ }^{24}$ Diversos números do Boletim da Faep/Senar tratam de visitas técnicas feitas a países da União Europeia com a finalidade de conhecer as experiências de obtenção de energia renovável para utilização em equipamentos de mobilidade e também na geração de energia elétrica. Cf. Amorim (2017), Itaipu (2017), Calderon (2017a, 2017b, 2017c), Guimarães Filho (2017).
} 
fazemos a queima sem aproveitar a energia gerada. A gerência de meio ambiente da CASAN informou que na região Sul do Brasil, a única experiência de geração de energia a partir do biogás é a da SANEPAR com a Catalini, citada anteriormente ${ }^{25}$.

$\mathrm{Na}$ entrevista com a Gerência de políticas operacionais da CASAN verificou-se que as ETEs da ilha algumas são com reator anaeróbico com queima de gás, por exemplo, a da Barra da Lagoa e a ETE da Lagoa da Conceição. Não há experiência de geração de energia nas ETEs pela queima do gás ${ }^{26}$. Sobre o projeto em andamento na ETE de Potecas, a gerência informou que pretende utilizar 4 reatores para coleta e queima de gás. Nas semanas seguintes à entrevista ${ }^{27}$ entraria em teste $\mathrm{o} 1^{\circ}$ reator, que servirá para fazerem os ajustes necessários. Após isto, irão ampliar o funcionamento para os outros três. Isto garantirá a eliminação de mais de $60 \%$ dos maus odores da ETE.

O mesmo entrevistado destacou que está evoluindo uma parceria entre Brasil e Áustria para desenvolver projetos para geração de energia, a partir da queima de gás da ETE de Canasvieiras e de produção de energia solar na Estação e Tratamento de Águas em Tubarão/SC, no Morro dos Quadros, que possui área ampla para esta aplicação ${ }^{28}$.

\subsection{Entrevistas com moradores do bairro Potecas}

Moradores entrevistados descreveram detalhadamente os transtornos provocados pelo gás sulfídrico e o mau cheiro no local em que se encontram as bombas elevatórias (Figura 6), na entrada da tubulação interna da ETE. O mau cheiro se intensifica quando ligam os motores das bombas de pressão e também quando há descarga de caminhões limpa fossa. São pessoas que tem náuseas, tontura, "queimação no peito", "queimação no esôfago", dores de cabeça, entre outros sintomas. O que chama a atenção é a exígua distância das casas que são separadas das lagoas de decantação, por apenas uma rua estreita. São casas que seguramente estão lá há mais de 10 anos. Observa-se na foto que as bombas elevatórias (estação de bombeamento) estão localizadas mais ou menos a 20 metros das primeiras casas do lado direito da rua. Isso

\footnotetext{
${ }^{25}$ Volto a este projeto piloto mais à frente no trabalho. Entrevista em 14 mar. 2018.

${ }^{26}$ Outra experiência é conduzida nas ETEs de Curitibanos e Canoinhas que é a técnica de flotação do material orgânico, o qual deve ser retirado com raspagem superficial do lodo suspenso. Sob esse lodo a água está clarificada para posterior despejo nos corpos de água.

${ }^{27}$ Entrevista realizada com Gerente de Políticas Operacionais no dia 02/03/2018.

${ }^{28}$ Também estão desenvolvendo projeto para geração de energia elétrica com turbina embutida na tubulação de água, pois a estação de águas de Tubarão possui grande desnível possibilitando o aproveitamento da energia hidráulica pela diferença de potencial do ponto mais alto e ponto mais baixo das tubulações.
} 
pode ser visualizado também na foto aérea (Fig.4) que localiza a ETE no bairro. As bombas elevatórias localizam-se na seta (B) centro direito da figura.

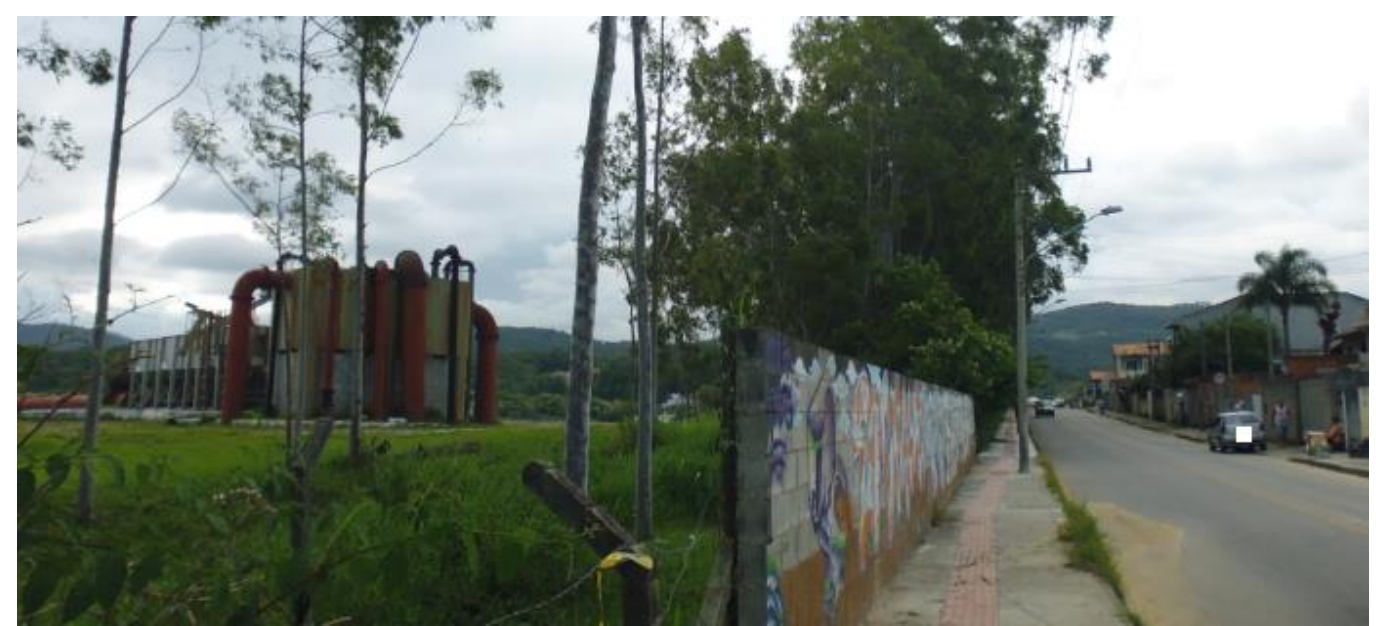

Figura 6 - Bombas elevatórias e casas próximas Fonte: Foto dos autores em 03/03/218.

Um dos moradores afirmou que a CASAN não desenvolve atividade de avaliação de risco dos gases emanados da estação. Deveriam ocorrer medições das concentrações do gás sulfídrico para medir o potencial do risco, no propósito de informa a população. As medições deveriam ser feitas em vários momentos de acordo com a intensidade percebida pelos moradores mais próximos e, em momentos de mudança operacional. O entrevistado considera que ao ligarem os motores das bombas e/ou quando descarregam os caminhões limpa fossa os maus odores se intensificam.

Os funcionários da Unidade Básica de Saúde de Potecas declararam que, na região, há incidência de problemas respiratórios, principalmente asma e bronquite, que atingem desde crianças até idosos. Além disso, há muitos casos de vômito e dor de cabeça entre os moradores. Nesta pesquisa não foi possível levantar o índice percentual de ocorrência das várias doenças para compará-la com incidência em outras populações que não sofram impactos de $\mathrm{ETEs}^{29}$. Além destes aspectos, seria importante levantar os casos de doenças neurológicas e mesmo morte súbita que não foram averiguadas. Declararam, ainda, que a ligação noturna das bombas de elevação espalha muito mau cheiro em todo o bairro.

Verificou-se in loco que os objetos - louças, metais, pinturas - sofrem uma espécie de oxidação, conforme alertaram os moradores. Os metais ficam enferrujados rapidamente e algumas pinturas mudam de cor ao serem cobertas com uma espécie de fuligem, tornando-se cinzentas. Os moradores se preocupam, pois consideram que o pulmão das pessoas deverá

\footnotetext{
${ }^{29}$ Fica como sugestão para estudos da área da saúde.
} 
ficar igual, ou seja, cheios de "fuligem". Para eles, isso seria efeito do gás sulfídrico. Em dias de chuva o mau cheiro se acentua, talvez por efeito das gotas de chuva que revolveriam a camada superficial dos lagos.

Talvez as bombas elevatórias, que também recebem descarga de caminhões, pudessem ser cobertas por uma grande lona formando algo parecido a um iglu e que permitiria a retenção de parte dos gases e evitaria espalhar bactérias que, com certeza, vaporizam na atmosfera por ocasião da descarga. A CASAN desprotege a população local e provoca crise ambiental, ao liberar para atmosfera gases causadores de efeito estufa e tóxicos e neurotóxicos aos humanos das redondezas. Os valores cobrados como taxa de tratamento de esgoto na Capital e em São José justificariam mais eficiência no tratamento. Isto não está ocorrendo. Há morosidade excessiva. Espera-se mais de uma companhia mista que recebe indicação política para suas presidências e diretorias.

Em tese, a resposta da CASAN não deveria tardar uma vez que ao menos um dos entrevistados afirmou que a empresa "não estaria fazendo nada" e estaria, também nas palavras do entrevistado, "apenas enrolando o povo". Um dos entrevistados da Casan confirmou notícias da mídia que há alguns anos houve vandalismo nas instalações, provocando dificuldades operacionais com os reatores anaeróbicos e lonas de coleta de gás que foram danificadas.

O que se verificou é que a empresa mudou o processo em 2009 implantando 4 reatores anaeróbicos com coleta e queima de biogás, mas que ao serem danificados precisaram de conserto e também estão mudando, agora em 2017/18, o processo de coleta do gás com reformas e manutenções dos mesmos equipamentos, conforme declaração. A Figura 7 mostra a explicação, durante a audiência pública de 2009, sobre o novo sistema que seria instalado na ETE de Potecas. Àquela época, a companhia já estava tentando sanar os problemas de maus odores apontados pela população. 


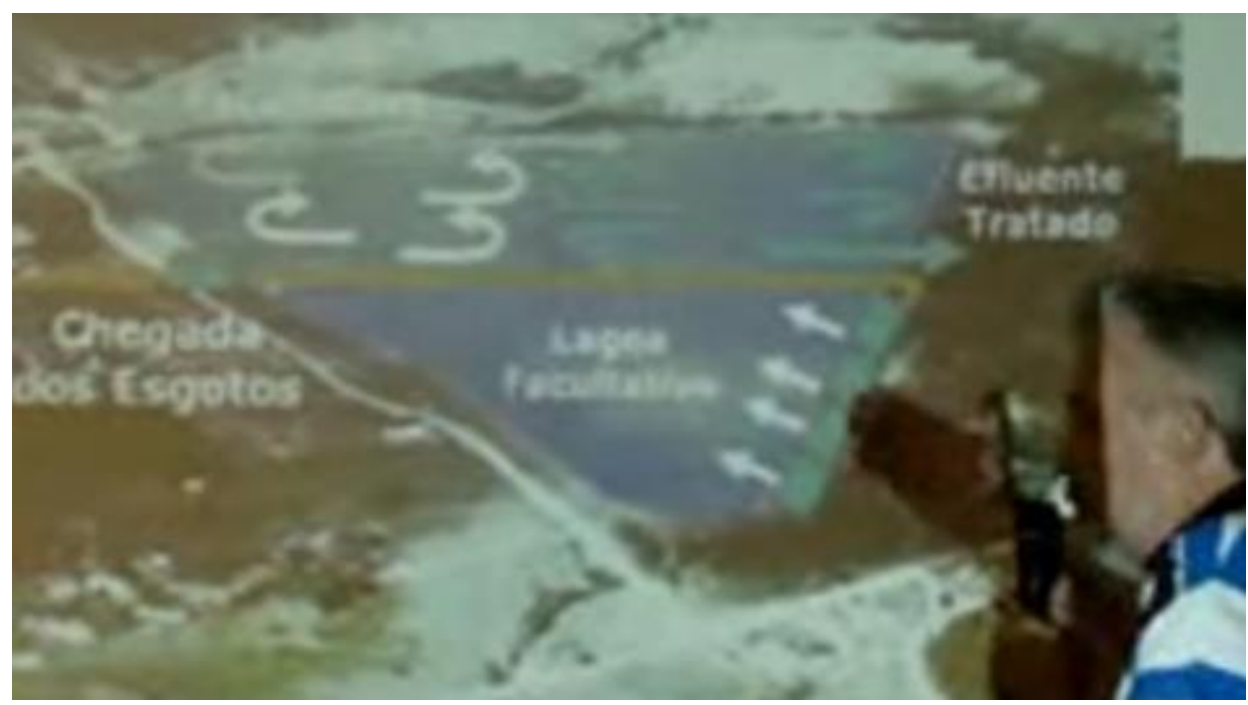

Figura 7 - Exposição técnica em audiência pública São José

Fonte: www.sjfoco.com.br. Data: 16/04/2009. Gravação Jornal São José em foco.

Naquela proposta de projeto de tratamento de esgoto também eram previstos 4 reatores anaeróbicos e queima de gás. Seria a solução para o grave problema da poluição do ar provocada pela estação de Potecas ${ }^{30}$. A companhia não conseguiu cumprir o prometido e precisou fazer nova audiência pública. Talvez a manutenção não fosse adequada, pois, o processo falhou.

Após 8 anos, nova audiência pública foi realizada, no Bairro Potecas, em 19 de outubro de 2017. Novamente, para ouvir e receber as reivindicações da população e explicar os novos projetos para a comunidade (Figuras 8 e 9). Foi realizada pela Comissão de Turismo e Meio Ambiente da Assembleia Legislativa com iniciativa proposta pelo deputado Mario Marcondes, representante de São José, sob argumento de ter recebido muitas reclamações da população local. O representante, na ocasião, declarou que pretendia propor ação popular pedindo o pagamento de danos coletivos aos moradores, enquanto a Casan não resolvesse a situação. "A comunidade local reclamou do odor causado pelos gases metano e sulfídrico provenientes da lagoa e cobrou soluções efetivas para melhorar a qualidade de vida no bairro" (COSTA, 2017).

\footnotetext{
${ }^{30}$ Vídeo original em: https://www.youtube.com/watch?v=moTMYh5faLQ.
} 

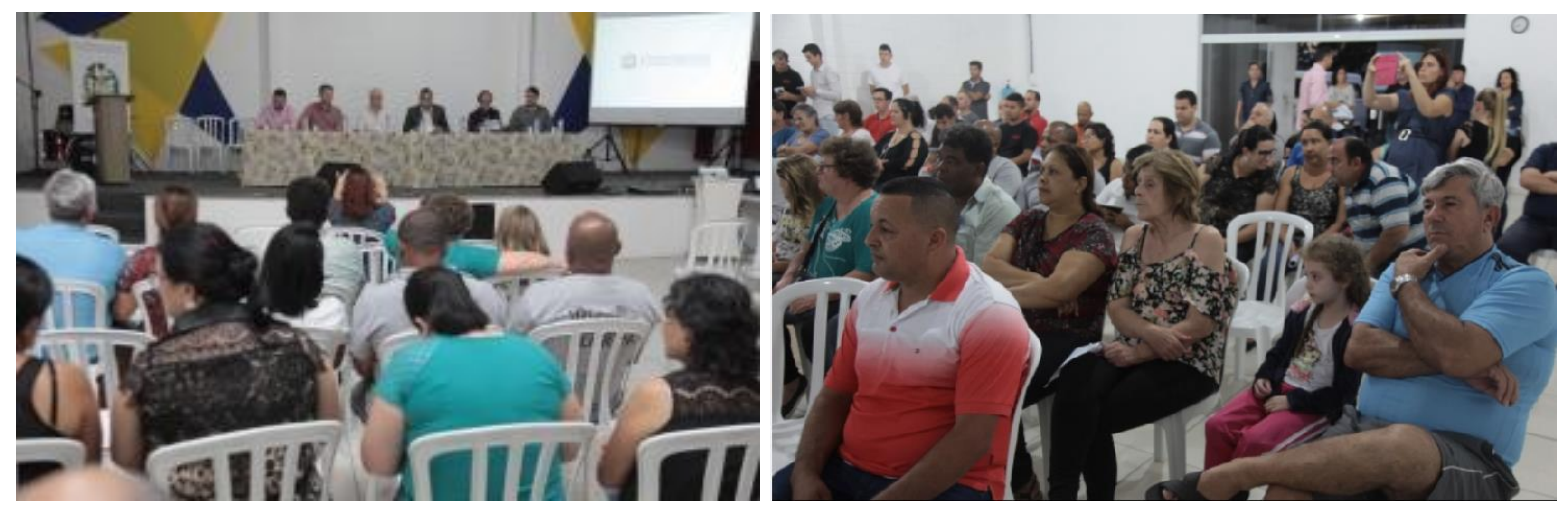

Figuras 8 e 9 - Realização de audiência pública da Assembleia Legislativa de SC no Bairro Potecas.

Fotos: Miriam Zomer/Agencia AL.

De acordo com o líder comunitário Jandir da Rosa, a situação vem se arrastando há mais de 30 anos. Ele disse que, além do odor insuportável, a acidez da lagoa vem causando problemas nos eletrodomésticos e veículos. Anos e anos de promessas já se passaram, e até agora nada. Há mais de 15 anos fazemos audiências públicas e corremos atrás de solução. Agora colocaram uma placa de que serão gastos mais de R \$ 3 milhões. Já estão acabando a obra, e o cheiro parece que aumenta cada vez mais (COSTA, 2017, p.1).

Naquele momento, o representante da CASAN pediu apoio da comunidade e informou que as primeiras soluções deveriam aparecer no final do ano, quando a obra de melhoria ficasse pronta. Não se concretizou esta promessa, uma vez que em entrevista concedida no final de fevereiro, recebemos informação que o primeiro reator deveria entrar em funcionamento no final deste mês ou início de março, como uma espécie de teste para posterior extensão de funcionamento aos demais. Parece que é mais uma das obras que andam a passo de tartaruga.

\section{Considerações finais}

Aparentemente, a solução da Cia Águas de Joinville parece ser definitiva com a construção de nova ETE no mesmo local da antiga e com novo processo - aeróbico. A CASAN poderá continuar encontrando dificuldades no futuro, pois permaneceu com o esquema que gera gás. Além disso, não estão modificando nada nas bombas elevatórias que também seriam geradoras de mau cheiro.

Quanto aos efeitos perversos da poluição do ar, verifica-se que aumenta a incidência de doenças respiratórias, náuseas e doenças neurológicas e mesmo mortalidade, conforme dados do PNUMA. As ETEs se não controlarem suas emanações contribuem negativamente 
para a saúde da população, bem como, para a emissão de gases efeito estufa o que significa externalidade negativa para toda a sociedade.

Os efeitos negativos das ETEs percebidos pela população geram manifestações, pressões políticas e judiciais buscando resolver os problemas de maus odores e gases tóxicos que prejudicam o seu bem estar.

Os tipos de tratamento para esgoto verificados no trabalho foram o anaeróbico (ETE Potecas/CASAN) e aeróbico (ETE Águas de Joinville). Ambas as estações analisadas foram construídas pela CASAN na década dos 90, e ambas tinham o mesmo sistema de tratamento e têm enfrentado pressão da população que cresceu no entorno ocupando o espaço próximo às estações. As famílias do entorno, ao ficarem expostas aos gases e ao "mau cheiro" que provocam irritação e doenças, passaram a pressionar para que fosse eliminado o problema. As soluções implementadas são diferentes, conforme foi constatado neste trabalho a partir de entrevistas e materiais divulgados na mídia. A Águas de Joinville resolveu mudar o processo de tratamento que passará a ser aeróbico ao invés de anaeróbico deste gerador de gases; e, a CASAN resolveu melhorar (reformar) o sistema de coleta e queima de gás para eliminar o mau cheiro, ou seja, continua com o processo anaeróbico. Além disso, a geração de maus odores do sistema de bombeamento da entrada da ETE de Potecas não sofrerá modificação e, portanto continuará a gerar mau estar para a população do seu entorno.

Verificou-se que atualmente não há aproveitamento energético de gases gerados nas ETEs, os quais são apenas queimados, embora estejam em perspectiva por parte da CASAN fazer parcerias para projetos piloto.

No Brasil, há potencial de produção de biogás a partir do tratamento de esgoto e de energia a contar da queima do mesmo. Considerando-se os baixos índices de coleta e tratamento de esgoto no Brasil, se a opção tecnológica for o tratamento anaeróbico do esgoto existiria elevado potencial de aproveitamento energético pela queima dos gases gerados no sistema, desde que ocorram os estímulos adequados para tal.

Não se vislumbraram estímulos financeiros para as companhias fazerem a transformação da queima do biogás em energia. A alteração de cobrança de ICMS em autogeração, aliada a maior clareza nos marcos regulatórios para o biogás, poderá deslanchar a produção de energia nas ETEs do país. O desenvolvimento tecnológico e experiência de outros países, como o caso da parceria da CASAN com a Áustria, poderão auxiliar no crescimento do uso do biogás para geração de energia nas ETEs e não simplesmente a sua queima como acontece atualmente. 


\section{Referências}

AGENDA ambiental tem a chance de ser valorizada. Valor Econômico, São Paulo, cad. A, p.12, 22 dez. 2017.

AMORIM, André. Mobilidade Verde. Boletim Informativo FAEP/SENAR, Curitiba, n. 1393, p.15-21, 26 jun. 2017.

BENETTI, Estela. SC isentará de ICMS alguns modelos de geração de energia. Diário Catarinense, Florianópolis, 13 mar. 2018.

BRASIL. LEI No 6.938, de 31 de agosto de 1981. Obtido em: http://www.planalto.gov.br/ccivil_03/LEIS/L6938.htm. Acesso em 15 de setembro de 2016.

CALDERON, Cynthia. Rota da Energia renovável. Boletim Informativo FAEP/SENAR, Curitiba, n. 1404, p. 12 - 15, 11 set.. 2017a.

. Energia que renova os Alpes. Boletim Informativo FAEP/SENAR, Curitiba, n. 1405 , p. 08 - 12 , 18 set.. 2017 b.

Itália estimula crescimento do setor de bioenergia. Boletim Informativo FAEP/SENAR, Curitiba, n. 1406, p. 08 - 13, 25 set. 2017c.

CARVALHO, Cleide Martins de. Odor e biodesodorização em reatores anaeróbios. 2001. Dissertação (Mestrado em Engenharia Ambiental) - Curso de Pós Graduação em Engenharia Ambiental, Universidade Federal de Santa Catarina, Florianópolis, 2001.

CASAN contrata melhorias para a ETE Potecas. São José. Floripa News. 19 dez. 2016. Obtido em http://www.floripanews.com.br/noticia/13358-casan-contrata-melhorias-para-aete-potecas Acesso jan.2018.

CHIARETTI, Daniela. Estudo lista desafios ambientais deste século. Valor Econômico, São Paulo, 26 fev. 2012, cad. A, p.9.

COSTA, Lisandrea. População cobra da Casan soluções para esgoto de Potecas/São José. Agência AL (Assembleia Legislativa Estadual de Santa Catarina). Florianópolis, 20 out. 2017. Obtido em: http://agenciaal.alesc.sc.gov.br/index.php/noticia_single/populacaeo-cobrada-casan-solucoes-para-esgoto-de-potecas-saeo-jose . Acesso em 20 fev. 2018.

DIAS, Claudio. Daae precisa de R\$ 30 milhões para evitar punição por tratamento de esgoto. Araraquara. 24/06/2917. Disponível em: https://www.acidadeon.com/araraquara/politica/eleicoes/NOT,3,7,1255634,Daae+precisa+de $+\mathrm{R}+30+$ milhoes + para+evitar+punicao+por+tratamento+de+esgoto.aspx. Acesso em 20/02/2018.

DREGER, Iara. Energias renováveis e aspectos ambientais. FAPESC/Governo de Santa Catarina (Slides). Florianópolis, 21 de set. 2017. Obtido em: https://www.embrapa.br/documents/1355242/0/Painel+2.pdf Acesso em 02/03/2018.

GARDEMANN, Alessandro. Brasil desperdiça energia limpa enquanto queima combustível fóssil (entrevista). ABIOGÁS Canal da Bionergia. 20 nov. 2017. Disponível em https://www.abiogas.org.br/brasil-desperdica-energia-limpa Acesso 26/02/2018.

GELINSKI NETO, Francisco; GELINSKI JUNIOR, Eduardo; ROGOSKI, Nédio Rogério. Biodigestores na suinocultura catarinense: relato de experiências de implantação. In: 55 Congresso da SOBER - Sociedade Brasileira de Economia, Administração e Sociologia Rural, 30 de julho a 03 agosto 2017, Santa Maria, SOBER. Anais... Obtido em: http://icongresso.itarget.com.br/tra/arquivos/ser.7/1/8321.pdf Acesso 02/02/2018. 
GUIMARÃES FILHO, Carlos. Uma referência para o Brasil. Boletim Informativo FAEP/SENAR, Curitiba, n. 1390, p.14 - 18, 05 jun. 2017.

ITAIPU e CIBiogás conhecem modelo de bionergia de Castro. Boletim Informativo FAEP/SENAR, Curitiba, n. 1397, p.24-25, 24 jul. 2017.

KISS, Janice. Documento propõe redução de emissões. Valor Econômico. São Paulo, 28 set. 2016. Cad. F, p.4.

MINISTÉRIO DA AGRICULTURA, PECUÁRIA E ABASTECIMENTO/MAPA. O Aquecimento Global e a Agricultura de Baixa Emissão de Carbono. Brasília MAPA / EMBRAPA / FEBRAPDP, 2011.

MARTENDAL, Luan. Investimentos. Diário Catarinense, Florianópolis, 20 fev. 2018, p. 19.

MUCCIACITO, João Carlos; CORDEIRO Selma Arruda. A saúde afetada pelos odores provenientes do efluente doméstico e o problema dos esgotos a céu aberto. Revista TAE. 6 out. 2014. Obtido em: http://tratabrasil.org.br/a-saude-afetada-pelos-odores-provenientes-doefluente-domestico-e-o-problema-dos-esgotos-a-ceu-aberto-2. Acesso em 2/03/2018.

PLATIAU, Ana Flávia Barros. O Brasil na governança das grandes questões ambientais contemporâneas. Texto de discussão IPEA, 1618. Brasília, maio 2011.

QI, Liyan. Pequim expulsa empresas para conter população. Valor Econômico, São Paulo. 12 ago. 2016, cad. A, p.11.

RESÍDUOS. SEEG Brasil. S.d. S.L. Obtido em: http://seeg.eco.br/panorama-residuos/ Acesso em 20/02/2018.

RODRIGUES, Dayse Laine; AQUINO, Camila Ferreira de; ESTEVAM, Giuliano Pierre. Produção de biogás a partir dos esgotos utilizando reatores anaeróbios do tipo rafa seguido por lodos ativados numa estação de tratamento de esgoto. Omnia Exatas, FATEC Araçatuba - SP, v.4, n.2, p.103-109, jul./dez. 2011.

TAIAR, Estevão. Investimentos em redes de esgoto recuam $26 \%$. Valor Econômico, São Paulo. 12 mar. 2018, cad. A, p.4.

THOMÉ, Rafael. Ação pede a remoção da Lagoa de Estabilização de Potecas para local mais adequado. Hora de Santa Catarina. Florianópolis, 24 out. 2017. Obtido em: http://horadesantacatarina.clicrbs.com.br/sc/geral/noticia/2017/10/acao-pede-a-remocao-da-

lagoa-de-estabilizacao-de-potecas-para-local-mais-adequado-9962752.html . Acesso em $\underline{05 / 03 / 2018}$.

TOLEDO, K. Quinto relatório do IPCC mostra intensificação das mudanças climáticas. Londres, Painel Brasileiro de Mudanças Climáticas. s.d. Obtido em http://www.pbmc.coppe.ufrj.br/pt/noticias/373-quinto-relatorio-do-ipcc-mostraintensificacao-das-mudancas-climaticas Acesso fev. 2018.

TRATA BRASIL. Estudo mostra que avanços em saneamento básico das Capitais nos últimos 5 anos foi insuficiente para tirar o Brasil do atraso histórico. GO Associados/ Instituto Trata Brasil. Fevereiro 2017. Obtido em: http://www.tratabrasil.org.br/datafiles/estudos/ranking/2017/press-release.pdf $\quad$ Acesso $27 / 02 / 2018$.

PNUD/MMA. Estudo sobre o Potencial de Geração de Energia a partir de Resíduos de Saneamento (lixo, esgoto), visando incrementar o uso de biogás como fonte alternativa de energia renovável (Resumo executivo - produto 6). Programa das Nações Unidas para o Desenvolvimento (PNUD) e Ministério do Meio Ambiente/Arcadis-Tetraplan. São Paulo, 2010. 
Revista Catarinense de Economia -RCE

APEC - Associação dos Pesquisadores em Economia Catarinense

1 은 Semestre de 2018 - www.apec.pro.br/rce

UPTON, Simon. O verdadeiro custo da poluição do ar. Valor Econômico, São Paulo, 16 ago. 2016, cad. A, p.11. 